\title{
Ambiente alimentar em São Leopoldo, Rio Grande do Sul, Brasil: associação com variáveis sociodemográficas da vizinhança
}

\author{
Food environment in São Leopoldo, Rio Grande do Sul, Brazil: \\ the association with neighborhood sociodemographic variables
}

Vanessa Backes (https://orcid.org/0000-0002-3860-7866) ${ }^{1}$
Juvenal Soares Dias da Costa (https://orcid.org/0000-0003-3160-6075) ${ }^{2}$
Fernanda Souza de Bairros (https://orcid.org/0000-0002-8611-058X) ${ }^{3}$
Cristina Borges Cafruni (https://orcid.org/0000-0002-3568-0785) ${ }^{4}$
Maria Teresa Anselmo Olinto (https://orcid.org/0000-0002-3950-4594) ${ }^{5}$

${ }^{1}$ Secretaria Municipal de Educação, Esporte e Lazer, Prefeitura Municipal de São Leopoldo. Av. Dom João Becker, Centro. 93022-250 São Leopoldo RS Brasil. nessabck@yahoo.com.br ${ }^{2}$ Programa de PósGraduação em Saúde Coletiva, Universidade do Vale do Rio dos Sinos. São Leopoldo RS Brasil. ${ }^{3}$ Programa de PósGraduação em Saúde Coletiva, Universidade Federal do Rio Grande do Sul. Porto Alegre RS Brasil.

${ }^{4}$ Colégio de Aplicação, Universidade Federal do Rio Grande do Sul. Porto Alegre RS Brasil.

${ }^{5}$ Programa de PósGraduação em Saúde Coletiva, Universidade do Vale do Rio dos Sinos. São Leopoldo RS Brasil.

\begin{abstract}
The scope of this study is to describe the food environment of a medium-sized municipality in southern Brazil and compare the availability of different types of food outlets in neighborhood socioeconomic and demographic environments. An ecological study was carried out in 45 buffers of $400 \mathrm{~m}$ in São Leopoldo county, RS. The buffer was calculated from the center point of the residences of women participating in a larger research project. All streets were surveyed to identify food stores and record their geographical coordinates, as well as apply the NEMS questionnaire on the availability, price and quality of 108 items. The commercial outlets were classified as supermarkets, grocery stores, fruit stores and convenience stores. Supermarkets and grocery stores were present in higher quantity in lower income buffers and grocery stores were more prevalent in those with higher population tertiles. Another result was a direct relationship between NEMS and tertile income scores for supermarkets, grocery stores and fruit stores, and an indirect relationship for the same stores and population tertile. The availability of healthy food was higher in areas with higher income and lower numbers of inhabitants, indicating the need for better distribution of food stores and availability of varieties of food in the municipality.
\end{abstract}

Key words Food environment, Buffer, Socioeconomic variables
Resumo O objetivo deste estudo é descrever o ambiente alimentar de um município de médio porte do Sul do Brasil e relacionar a disponibilidade de diferentes tipos de comércios de alimentos com características socioeconômicas e demográficas do entorno. Trata-se de estudo ecológico em 45 buffers, de 400m, em São Leopoldo, Rio Grande do Sul. O buffer foi calculado a partir do centróide das residências das mulheres participantes de um projeto de pesquisa maior. Todas as ruas foram percorridas para a identificação dos estabelecimentos de alimentos, que tiveram suas coordenadas geográficas registradas, bem como foram avaliados, através do questionário NEMS (Nutrition Environment Measures Survey in Stores), sobre disponibilidade, preço e qualidade de 108 itens. Os comércios foram classificados em supermercados, mercearias, fruteiras e lojas de conveniência. Os supermercados e as mercearias estavam em maior número nos buffers de menor renda e mercearias mais presentes naqueles de maior tercil populacional. Observa-se relação direta entre escores do NEMS e tercil de renda para supermercados, mercearias e fruteiras e indireta para os mesmos comércios e tercil populacional. A disponibilidade de alimentos saudáveis se mostrou mais elevada em áreas de maior renda e menor número de habitantes, o que sinaliza a necessidade de melhor distribuição dos comércios e variedades de alimentos. Palavras-chave Ambiente alimentar, Buffer, Socioeconômico 


\section{Introdução}

O processo de urbanização ocorrido nas últimas décadas no Brasil e no mundo, aliado a intensas mudanças econômicas e sociais, provocou importantes transformações nas condições de saúde da população, uma vez que diversas doenças estão associadas ao ambiente onde a pessoa vive e seu entorno ${ }^{1,2}$. No âmbito da saúde coletiva, $o$ estudo da influência que o ambiente exerce sobre a saúde da população é milenar e de destaque, por estar associado com as escolhas e o comportamento dos indivíduos, e afeta diretamente as condiçõos de saúde ${ }^{3-6}$. Hipócrates, 500 a.C, em Ares, águas e lugares já procurava demonstrar a influência dos fatores ambientais na ocorrência de doenças?. John Snow, em seu estudo sobre o modo de transmissão do cólera, investigou a distribuição espacial da doença ${ }^{8}$. Engels, em 1844, evidenciou maior mortalidade de indivíduos vivendo em situação de vulnerabilidade quando comparados àqueles com melhores condições de vida, em seus estudos sobre o impacto da industrialização na saúde da população9. No Brasil, Josué de Castro, na década de 1930, investigou as condições de vida da classe operária nordestina, o que originou o livro Geografia da fome, onde o autor introduz o conceito de áreas alimentares, hoje chamado de ambiente alimentar ${ }^{10}$. O ambiente alimentar pode ser definido pelo território em que se vive e trabalha e que gera impacto sobre a qualidade da alimentação da população ${ }^{11}$. Ele sofre influências contextuais, como econômicas, políticas e socioculturais, e individuais, através das crenças sociais, religiosas, culturais, bem como os modos de consumir ${ }^{12,13}$ e as escolhas alimentares.

Quando o ambiente oportuniza melhores opções, as chances das pessoas adquirirem comportamentos saudáveis são maiores. Porém, a falta de acesso ao alimento e a insegurança alimentar ainda são realidades vividas por indivíduos em todo o mundo, principalmente para aqueles de países subdesenvolvidos ${ }^{14}$. Observa-se que em regiões de menor poder aquisitivo o preço dos alimentos são mais altos e a qualidade mais baixa e que a quantidade e variedade de alimentos disponíveis nestes bairros são isalubres ${ }^{15,16}$.

Dados de estudos realizados em países desenvolvidos apontam que indivíduos que vivem em comunidades com maior vulnerabilidade social apresentam maior dificuldade de acesso a alimentos saudáveis ${ }^{17-20}$. Por outro lado, observase que vizinhanças favorecidas economicamente apresentam maior número e maior densidade de comércios - que é a razão do número de comércio de alimentos pela população local - como supermercados e lojas especializadas na venda de frutas e hortaliças, o que estaria associado a maior disponibilidade, acesso e consumo de alimentos saudáveis $^{21-23}$. No Brasil, estudos que exploram o ambiente alimentar mostram uma densidade e qualidade dos alimentos diferentes conforme os níveis de renda da populaçãa ${ }^{24-26}$.

Entretanto, ainda não está claro na literatura existente se estas relações se dão da mesma forma em diferentes contextos socioeconômicos. Estas contradições podem ser explicadas por questões culturais, geográficas, mas também pelas diversas metodologias empregadas para avaliar o mesmo efeito ${ }^{27}$. As diferentes medidas utilizadas avaliam tanto no nível comunitário, através da densidade e localização dos estabelecimentos de comércio de alimentos, por exemplo, quanto no nível do consumidor, com avaliação da disponibilidade, a variedade, o preço, e a qualidade dos alimentos no comércio, o que caracteriza o comércio em saudável ou não saudável ${ }^{28}$. Muitos estudos, no entanto, fazem uma avaliam o ambiente em saudável ou não saudável a partir da classificação comercial, a exemplo, o supermercado ${ }^{29,30}$. Esta classificação pode ser arbitrária, e uma de suas limitações é que normalmente o comércio oferece ambos os tipos de alimentos, o que dificulta a classificação dos estabelecimentos e a interpretação dos dados ${ }^{20}$.

Assim, este estudo utiliza instrumentos de avaliação do ambiente alimentar urbano e investiga se o acesso aos alimentos saudáveis, medidos através de auditagens, varia em diferentes tipos de lojas e em diferentes condições sociodemográficas. Tem como objetivo descrever o ambiente alimentar de um município de médio porte do Sul do Brasil e associar este ambiente com características sociodemográficas do entorno.

\section{Métodos}

Este estudo originou-se de um projeto maior, intitulado "Condições de Vida e Saúde de Mulheres Adultas: Estudo de Base Populacional no Vale dos Sinos - Avaliação após 10 anos", e que avaliou 1.125 mulheres de 45 anos, dos 371 setores censitários na zona urbana do município de São Leopoldo, Rio Grande do Sul, Brasil. O município está situado na região do Vale do Rio dos Sinos, Região Metropolitana de Porto Alegre. Em 2010, apresentava população de 214.087 habitantes e seu índice de desenvolvimento humano (IDH) 
era 0,739 , considerado alto para os parâmetros nacionais ${ }^{31}$. A partir das coordenadas geográficas, obtidas com auxílio de um GPS, das residências das mulheres pertencentes à pesquisa, para cada setor censitário, foi calculado o ponto mediano, centroide, de todas estas residências, e definido um buffer, círculo com raio de $400 \mathrm{~m}$ gerado a partir da localização do ponto mediano ${ }^{32}$. Estas definições foram possíveis com a utilização do software ArcGIS. Na posse do mapa com as ruas do buffer, a área foi percorrida, a pé, por pesquisadores treinados, para identificação e registro das coordenadas geográficas em GPS de todos os estabelecimentos de venda de alimentos para consumo no domicílio existentes, independente de serem formais ou informais. Posteriormente, realizou-se a auditagem dos estabelecimentos, através de visita para a aplicação de um questionário, baseado no NEMS (Nutrition Environment Measures Survey in Stores).

O NEMS foi validado em 2007, nos Estados Unidos e posteriormente validado no Brasi ${ }^{33,34}$. Através dele, é possível avaliar a disponibilidade e o preço de 108 itens alimentares, bem como a qualidade das frutas e verduras comercializadas. Levando em consideração a disponibilidade e o preço para todos os itens bem como a qualidade de frutas e verduras, calcula-se um escore que pode variar de -30 a 100. Posteriormente, os estabelecimentos são categorizados em: não saudáveis, intermediários e saudáveis. A partir da classificação dos alimentos, gera-se um escore para o estabelecimento. Quanto maior este valor, mais saudável é o estabelecimento.

O desfecho do estudo é o ambiente alimentar, avaliado através do escore acima mencionado, $\mathrm{o}$ número e tipo de comércio, bem como a densidade de estabelecimentos para cada 1.000 habitantes, em cada um dos 45 buffers avaliados. Os tipos de comércios foram classificados em supermercado (grandes redes, com venda de alimentos e outros itens, como produtos de limpeza, utensílios de cozinha), mercearias (minimercados de bairro, com predominância de venda de alimentos), lojas de conveniência (comércio de alimentos vinculado a um posto de combustível) e fruteiras (comércio essencialmente de frutas e verduras). As variáveis independentes foram: média de renda domiciliar e média de moradores dos buffers estudados. Calculada a partir da renda domiciliar dos moradores maiores de 10 anos dividido por 1000 e de moradores dos setores censitários que continham o centróide dentro do buffer, utilizando como referência os dados do Censo $2010^{31}$. Para a utilização destas variáveis, realizou-se uma análise da qualidade da informação, a partir da média, a mediana e o intervalo interquartil da renda domiciliar e de moradores dos setores censitários que pertenciam ao buffer e nenhum valor discrepante foi identificado. Para a análise estatística utilizou-se o tercil da renda e o tercil do número médio de moradores dos buffers avaliados.

A confiabilidade inter-avaliador, ou seja, a avaliação da extensão com que um instrumento de avaliação leva aos mesmos resultados num intervalo de tempo, realizada em $20 \%$ da amostra, com espaçamento de 15 a 60 dias, utilizando o coeficiente de correlação intraclasse (ICC), apresentou o valor de 0,81 , considerado excelente ${ }^{35}$.

As coordenadas geográficas foram exportadas para o Programa ArcGis (ESRI ${ }^{\circledR}$ ) versão 10.3 e através dele foi possível calcular e definir os $b u$ ffers, bem como, elaborar os mapas. A entrada de dados referente ao questionário aplicado nos comércios de alimentos foi realizada no programa EpiData, versão 3.1, em dupla entrada e posterior comparação, para se eliminar a probabilidade de erros de digitação. As análises dos dados foram conduzidas no programa Stata versão 12.0 (Stata Corp., College Station, Estados Unidos) e SPSS versão 23.0 (Statistical Package for the Social Sciences).

Foram realizadas análises descritivas, com avaliação da média, mediana, valores mínimos e valores máximos, considerando que todas as variáveis foram analisadas de forma contínua. Para medir o grau de correlação entre as médias dos diferentes tipos de comércios de alimentos, obtidas com o questionário NEMS, e ainda destas médias com variáveis econômicas (renda domiciliar) e demográficas (número de moradores por buffer), utilizou-se a análise de correlação linear de Sperman, considerando que a distribuição das variáveis era assimétrica. A distribuição dos comércios nos diferentes tercis de renda e de número de moradores foram avaliadas através da comparação de médias, Anova.

O protocolo de pesquisa da primeira fase da pesquisa, que envolvia humanos, foi aprovado pelo Comitê de Ética em Pesquisa da Universidade do Vale do Rio dos Sinos.

\section{Resultados}

Entre os 45 buffers avaliados, a média de moradores foi de 575,91, com 2,22 moradores por domicílio. Observou-se uma renda média domiciliar per capita mensal de $\mathrm{R} \$ 934,29$, ou seja, menos de 
um salário mínimo (salário da época da coleta, no Rio Grande do Sul, era de R\$1.006,88). Com relação ao ambiente alimentar, 279 comércios de alimentos foram avaliados, e aqueles localizados nas intersecções dos buffers, considerados em ambas as áreas, totalizaram 395. De todos os buffers avaliados, apenas um não apresentava nenhum comércio de alimentos. A média mais e menos frequente de comércios de alimentos por buffer foi a de mercearias $(5,53)$ e loja de conveniência $(0,55)$, respectivamente. Porém, ao analisar a densidade de comércios por número de habitantes na área, a maior média encontrada foi a de supermercados $(7,07)$, seguida pelas mercearias $(6,77)$. O escore NEMS foi utilizado para a classificação dos comércios conforme oferta de alimentos saudáveis e não saudáveis. A variação do escore foi de - 16 a 55 , em que os supermercados $(25,44)$ e as fruteiras $(23,45)$ apresentaram o maior escore, porém ambos com uma grande variação interna (DP de 24,5 e 22,0, respectivamente). Estas características sociais e relativas ao ambiente alimentar de São Leopoldo estão apresentadas na Tabela 1.

A Tabela 2 mostra a análise de correlação de Spearman entre as variáveis relativas ao ambiente alimentar e as sociodemográficas. Supermercado apresentou uma correlação positiva com mercearias $(0,223)$, fruteiras $(0,197)$ e número de moradores $(0,195)$, ou seja, quanto maior o número destes três últimos, maior o número de supermercados. Por outro lado, os supermercados apresentaram uma correlação negativa com loja de conveniência $(-0,417)$ e renda domiciliar $(-0,484)$, ou seja, quanto menor o número de lojas de conveniência e a renda total dos moradores daquela área, maior o número de supermercados. As mercearias e as fruteiras apresentaram tendência similar, diferente das lojas de conveniência que apresentaram correlação positiva com a renda domiciliar $(0,549)$ e negativa com o número de moradores $(-0,320)$.

$\mathrm{Na}$ Figura 1 são apresentados os dados da densidade de comércios de alimentos pela população e renda do . Observa-se uma relação direta entre número de moradores e número de comércios de alimentos e uma relação inversa entre estes e a renda, ou seja, buffers com menor renda e maior número de moradores tinham o maior número de comércios, enquanto buffers de maior renda e menor número de moradores tinham menor disponibilidade de comércios de alimentos.

O número dos comércios de alimentos, bem como o escore do NEMS de cada um deles foi analisado nos diferentes tercis de renda dos $b u$ ffers ( $1^{\circ}$ tercil: $<\mathrm{R} \$ 642,80 ; 2^{\circ}$ tercil: $\mathrm{R} \$ 642,80 \mathrm{a}$ R \$ 939,84; 3 o tercil: R \$ >939,84, salário mínimo

Tabela 1, Características socioeconômicas e ambientais dos buffers ${ }^{\star}$,

\begin{tabular}{lrrrr}
\hline \multicolumn{1}{c}{ Variável } & média $(\mathbf{D P})$ & mediana & mín, & máx, \\
\hline Número de buffers & 45 & & & \\
Número de moradores & $575,91(149,27)$ & 563,4 & 331 & 1103 \\
Número de moradores por domicílio & $2,22(0,64)$ & 2,11 & 1,05 & 4,48 \\
Renda domiciliar per capita mensal & $934,29(531,95)$ & 715,01 & 381,01 & 2436,42 \\
Estabelecimentos de alimentos por buffer & & & & \\
$\quad$ Supermercado & $3,82(2,31)$ & 3,00 & 0,00 & 8,00 \\
$\quad$ Mercearia & $5,53(4,32)$ & 4,00 & 0,00 & 14,00 \\
$\quad$ Loja conveniência & $0,55(1,07)$ & 0 & 0 & 4,00 \\
$\quad$ Fruteiras & $0,76(0,76)$ & 1,00 & 0 & 2,00 \\
Densidade de estabelecimentos (por 1000 habitantes) & & & & \\
$\quad$ Supermercado & $7,07(4,80)$ & 5,58 & 0 & 18,92 \\
$\quad$ Mercearia & $6,77(5,44)$ & 4,54 & 0 & 20,09 \\
$\quad$ Loja conveniência & $1,41(2,78)$ & 0 & 0 & 11,7 \\
$\quad$ Fruteiras & $1,26(1,25)$ & 1,34 & 0 & 4,82 \\
Escore NEMs & & & & \\
$\quad$ Supermercado & $25,44(14,55)$ & 24,5 & $-2,00$ & 55,00 \\
$\quad$ Mercearia & $9,73(10,92)$ & 8,00 & $-12,00$ & 44,00 \\
$\quad$ Loja conveniência & $-7,36(4,89)$ & $-8,00)$ & $-16,00$ & 3,00 \\
Fruteiras & $23,45(11,90)$ & 22,00 & 3,00 & 50,00 \\
\hline
\end{tabular}

${ }^{*} 400 \mathrm{~m}$ do centroide das residências das mulheres participantes do estudo original,

Fonte: Elaborada pelos autores. 
Tabela 2. Correlação de Spearman por características sociodemográficas do entorno e variáveis do ambiente alimentar.

\begin{tabular}{|c|c|c|c|c|c|c|}
\hline Variável & Supermercado & Mercearia & $\begin{array}{c}\text { Loja } \\
\text { conveniência }\end{array}$ & Fruteira & População\# & $\begin{array}{l}\text { Renda } \\
\text { total }^{@}\end{array}$ \\
\hline Supermercado & 1,00 & - & - & - & - & - \\
\hline Mercearia & 0,223 & 1,00 & - & - & - & - \\
\hline Loja conveniência & $-0,417$ & $-0,092$ & 1,00 & - & - & - \\
\hline Fruteira & 0,197 & 0,234 & 0,111 & 1,00 & - & - \\
\hline *População & 0,195 & 0,422 & $-0,320$ & 0,209 & 1,00 & - \\
\hline${ }^{* *}$ Renda total & $-0,484$ & $-0,483$ & 0,549 & $-0,044$ & $-0,577$ & 1,00 \\
\hline
\end{tabular}

regional na época: $\mathrm{R} \$ 1.006,88)$. No menor e no maior tercis de renda as mercearias apresentaram maior frequência, 52,3\% e 40,9\%, respectivamente. Já no segundo tercil de renda, os supermercados foram os mais frequentes $(48,6 \%)$, quando comparados às mercearias, fruteiras e lojas de conveniência. As lojas de conveniência foram as menos frequentes nos $1^{\circ}$ e $2^{\circ}$ tercis $(1,1$ e $8,3 \%$, respectivamente), enquanto as fruteiras foram as menos frequentes no maior tercil de renda $(10,6 \%)$. Observa-se que a média do número de supermercados e mercearias foi maior no $1^{\circ}$ tercil de renda, enquanto que a de fruteiras foi no $2^{\circ}$ tercil de renda. As lojas de conveniência apresentaram maior média no terceiro tercil de renda. Porém, ao analisar o escore do NEMS, percebe-se que para supermercado, mercearia e fruteiras quanto maior o tercil de renda, maior o escore, indicando maior disponibilidade de produtos considerados saudáveis quando comparados aos não saudáveis. As lojas de conveniência mostraram a mesma direção, porém para os alimentos não saudáveis, ou seja, quanto maior a renda, maior a disponibilidade de alimentos não saudáveis (Tabela 3).

$\mathrm{Na}$ Tabela 4 são apresentadas a distribuição e o número médio dos comércios de alimentos, bem como o escore do NEMS de cada um deles nos diferentes tercis populacionais dos buffers ( $1^{\circ}$ tercil: $\left\langle 523,87 ; 2^{\circ}\right.$ tercil: 523,87 a 629,50 ; $3^{\circ}$ tercil: $>629,50)$. No $1^{\circ}$ e $2^{\circ}$ tercis populacionais os supermercados apresentaram maior frequência, $48,1 \% \%$ e $45,9 \%$, respectivamente. Já no terceiro tercil as mercearias foram os mais frequentes $(47,5)$, comparados aos supermercados, fruteiras e lojas de conveniência. As lojas de conveniência foram as menos frequentes nos tercis 1 e $3(9,1$ e 3,4\%, respectivamente), enquanto as fruteiras foram as menos frequentes no segundo tercil
(4,7\%). Observa-se uma relação direta entre a média de supermercados, mercearias e fruteiras com o número de moradores, pois há um aumento na média destes comércios do $1^{\circ}$ para o $3^{\circ}$ tercil. O inverso ocorre com as lojas de conveniência, que apresentam a menor média nos buffers mais populosos. Porém, ao analisar o escore do NEMS percebe-se que para supermercado, mercearias e fruteiras, buffers menos populosos apresentam melhor escore quando comparados aos maios populosos. Porém, as lojas de conveniência apresentam piores escores nos bairros mais populosos quando comparadas aos de $1^{\circ}$ tercil.

\section{Discussão}

O presente trabalho explorou o ambiente alimentar ao avaliar os tipos de comércios de alimentos existentes nos buffers estudados segundo a renda e número de habitantes de diferentes regiões urbanas de um município de médio porte do Sul do Brasil.

Entre os comércios avaliados, os resultados apontaram um maior predomínio de mercearias e menor de lojas de conveniência nos 45 buffers estudados. Os supermercados e as lojas de conveniência apresentaram o maior e o menor escores do NEMS, respectivamente e o escore aumentava conforme o aumento de renda e diminuía conforme o aumento do número de habitantes dos buffers.

Dados nacionais oriundos da Pesquisa de Orçamento Familiar de 2008-2009 mostram que $54 \%$ dos gastos familiares com alimentação foram realizados em supermercados, enquanto que as mercearias ficaram apenas com $17 \%{ }^{36}$. Estudos apontam que os supermercados juntamente com as fruteiras são os comércios que oferecem 

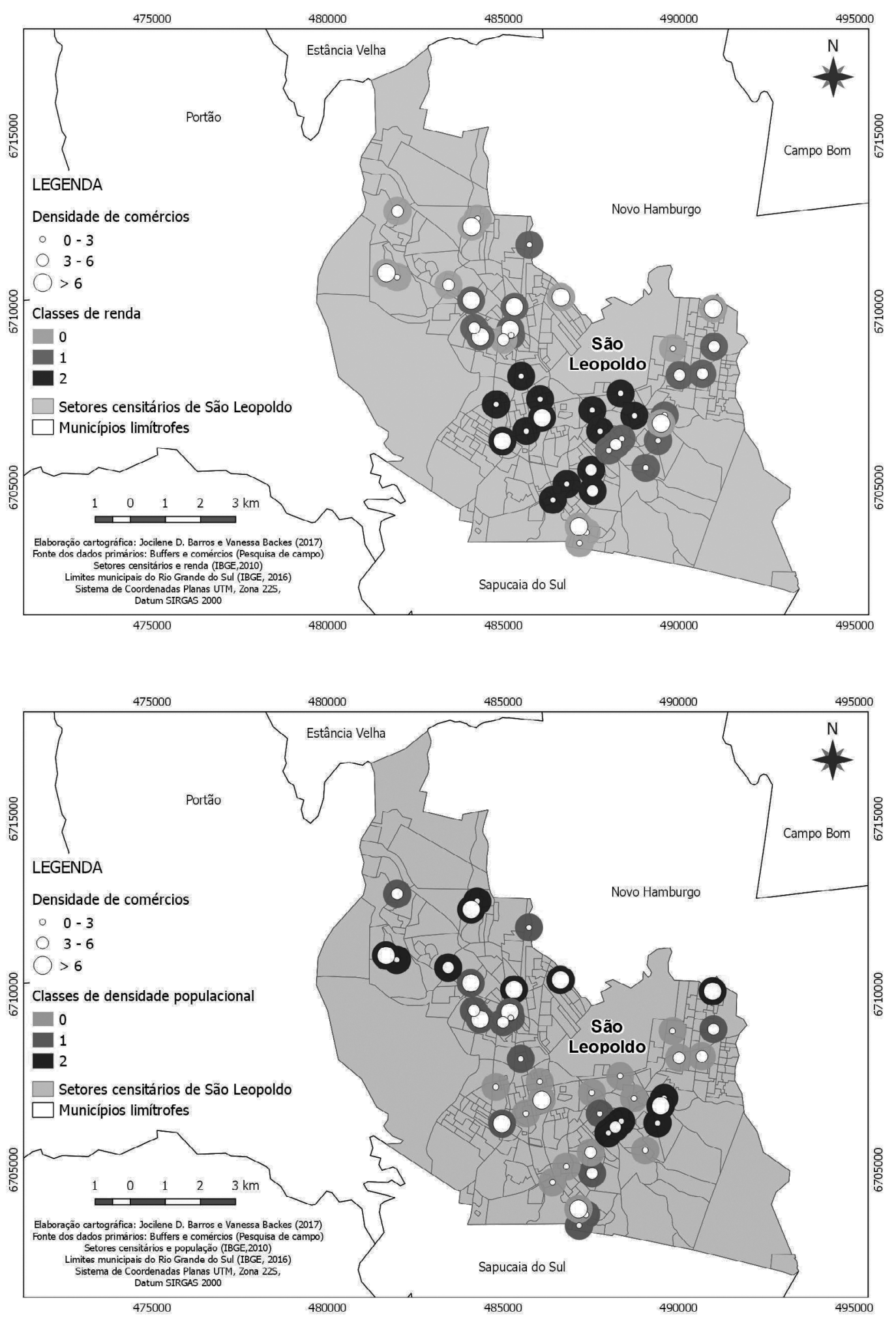

Figura 1. Distribuição dos estabelecimentos de alimentos por renda e densidade populacional do buffer.

Fonte: Elaborada pelos autores. 
Tabela 3. Distribuição (\%) do tipo de estabelecimentos, média (DP) dos estabelecimentos, conforme os tercis de renda do buffer*

\begin{tabular}{|c|c|c|c|c|c|c|c|}
\hline & \multicolumn{6}{|c|}{ Renda do buffer } & \multirow{3}{*}{ p (Anova) } \\
\hline & \multicolumn{2}{|r|}{1 tercil } & \multicolumn{2}{|r|}{2 tercil } & \multicolumn{2}{|r|}{3 tercil } & \\
\hline & $\%$ & média (DP) & $\%$ & média (DP) & $\%$ & média (DP) & \\
\hline \multicolumn{8}{|c|}{ Tipo de estabelecimentos } \\
\hline Supermercado & & $5,12(1,93)$ & & $3,8(2,40)$ & & $2,39(2,09)$ & $<0,001$ \\
\hline Mercearia & & $5,84(4,75)$ & & $2,25(0,91)$ & & $3,28(2,87)$ & $<0,001$ \\
\hline Loja conveniência & & $0,15(0,35)$ & & $0,62(0,71)$ & & $1,45(1,50)$ & $<0,001$ \\
\hline Fruteiras & & $0,69(0,74)$ & & $1,17(0,76)$ & & $0,60(0,62)$ & $<0,001$ \\
\hline \multicolumn{8}{|l|}{ Escore NEMS } \\
\hline Supermercado & 43,2 & $21,39(12,85)$ & 48,6 & $27,17(15,24)$ & 33,3 & $28,00(15,53)$ & 0,133 \\
\hline Mercearia & 52,3 & $7,95(9,79)$ & 30,6 & $8,44(7,90)$ & 40,9 & $15,23(14,12)$ & 0,012 \\
\hline Loja conveniência & 1,1 & $-1,5(6,36)$ & 8,3 & $-7,16(5,81)$ & 15,2 & $-8,54(3,69)$ & 0,175 \\
\hline Fruteiras & 3,4 & $19,42(8,10)$ & 12,5 & $19,4(8,44)$ & 10,6 & $33,28(14,55)$ & 0,026 \\
\hline
\end{tabular}

Tabela 4. Distribuição (\%) do tipo de estabelecimentos, média (DP) dos estabelecimentos, conforme os tercis do número populacional do buffer*

\begin{tabular}{|c|c|c|c|c|c|c|c|}
\hline & \multicolumn{6}{|c|}{ Número populacional } & \multirow{3}{*}{ p (Anova) } \\
\hline & \multicolumn{2}{|c|}{1 tercil } & \multicolumn{2}{|r|}{2 tercil } & \multicolumn{2}{|r|}{3 tercil } & \\
\hline & $\%$ & média (DP) & $\%$ & média (DP) & $\%$ & média (DP) & \\
\hline \multicolumn{8}{|c|}{ Tipo de estabelecimentos } \\
\hline Supermercado & & $4,01(2,79)$ & & $3,5(1,8)$ & & $4,66(2,34)$ & 0,002 \\
\hline Mercearia & & $1,97(1,19)$ & & $3,6(2,7)$ & & $6,29(4,86)$ & $<0,001$ \\
\hline Loja conveniência & & $0,54(0,61)$ & & $1,2(1,5)$ & & $0,18(0,39)$ & $<0,001$ \\
\hline Fruteiras & & $0,75(0,74)$ & & $0,4(0,5)$ & & $1,08(0,80)$ & $<0,001$ \\
\hline \multicolumn{8}{|l|}{ Escore NEMS } \\
\hline Supermercado & 48,1 & $33,13(12,04)$ & 45,9 & $23,1(14,9)$ & 40,7 & $21,39(13,96)$ & $<0,001$ \\
\hline Mercearia & 29,9 & $22,06(17,52)$ & 40,0 & $16,2(16,1)$ & 47,5 & $13,54(13,60)$ & 0,001 \\
\hline Loja conveniência & 9,1 & $-5,85(4,94)$ & 9,4 & $-8,1(5,9)$ & 3,4 & $-8,5(1,91)$ & 0,611 \\
\hline Fruteiras & 13,0 & $28,5(15,60)$ & 4,7 & $21,2(3,3)$ & 8,5 & $19,30(11,90)$ & 0,213 \\
\hline
\end{tabular}

${ }^{\star} 1^{\circ}$ tercil: $<523,87 ; 2^{\circ}$ tercil: 523,87 a 629,$50 ; 3^{\circ}$ tercil: $>629,50$.

Fonte: Elaborada pelos autores.

alimentos saudáveis aos consumidores, enquanto que mercearias e lojas de conveniência oferecem mais alimentos industrializados, bebidas açucaradas e pouca ou nenhuma variedade de frutas e verduras $^{37-42}$.

Entre os comércios avaliados pela atual pesquisa, aqueles mais frequentes foram as mercearias e os supermercados, enquanto que lojas de conveniência e fruteiras apresentaram uma média menor que um por buffer. Sabe-se que a disponibilidade dos comércios não garante acesso a alimentos de qualidade, pois nem sempre eles estão presentes e em alguns casos o preço, princi- palmente daqueles alimentos considerados saudáveis, inviabiliza a aquisição ${ }^{43}$. Muitos estudos classificam os comércios de alimentos em saudáveis e não saudáveis apenas pela sua classificação - fruteira como saudável e loja de conveniência não saudável, por exemplo -, sem uma avaliação dos alimentos disponíveis para comercialização no estabelecimento. Porém, a classificação dos comércios de alimentos que utiliza apenas o tipo como parâmetro pode gerar falsas conclusões. Para colaborar com esta classificação, alguns métodos de avaliação do ambiente são propostos, entre eles o NEMS, utilizado nesta pesquisa, 
e que possibilita identificar a disponibilidade e o custo dos alimentos saudáveis e não saudáveis, bem como a qualidade das frutas e verduras. Diez e colaboradores ${ }^{44}$, ao utilizar o mesmo questionário para comparar o ambiente alimentar de Baltimore e Madrid, encontraram um maior escore do NEMS entre os supermercados e as mercearias, indicando uma maior presença de opções de alimentos saudáveis nestes comércios ${ }^{44}$. No mesmo sentido, Cannuscio e colaboradores ${ }^{45}$, ao avaliarem o ambiente alimentar da Filadélfia, encontraram maiores escores do NEMS para mercearias $(21,67)$ e supermercados $(38,41)$, e menores para lojas de conveniência $(11,11)^{45}$. Porém, outro estudo americano, que avaliou a disponibilidade de alimentos em mercearias, concluiu que os alimentos saudáveis estavam menos disponíveis e eram mais caros que aqueles considerados não saudáveis ${ }^{46}$.

Cabe salientar que este questionário foi validado no Brasil em um momento em que a política de promoção da alimentação adequada baseava-se em um guia alimentar prescritivo que indicava o número de porções diárias dos grupos alimentares, considerando a composição nutricional dos alimentos, semelhante ao NEMS. Porém, o atual guia alimentar para a população brasileira estabelece uma nova abordagem, e que classifica os alimentos conforme o grau de processamento e leva em consideração questões relativas ao ato de comer e a comensalidade, com orientação das compras dos alimentos em feiras, o desenvolver, exercitar e partilhar habilidades culinárias, dar à alimentação o espaço que ela merece, entre outras ${ }^{47,48}$. Assim, há um indicativo da necessidade de elaboração de um novo instrumento que avalie a qualidade dos alimentos ofertados nos comércios, que considere o grau de processamento de alimentos, que classifique os grupos em in natura ou minimamente processados, que identifique ingredientes culinários, alimentos processados e ultraprocessados - aqueles que passaram pelo processamento, com mistura de ingredientes - a fim de criar produtos duráveis, acessíveis e práticos ${ }^{48-50}$.

Porém, os achados encontrados através no NEMS permitem algumas considerações. Uma delas é a diferença dos escores encontrados nos 4 tipos de estabelecimentos estudados, pois enquanto que supermercados apresentavam escore médio de 25,44 (DP 14,55), as lojas de conveniência tinham média de escore de -7,36 (DP 4,89). Justamente pela qualidade dos alimentos ofertados, existe a preocupação do acesso a diferentes tipos de comércios de alimentos. Enquanto mui- tos oferecem na sua maioria alimentos saudavéis, outros comercializam alimentos ultraprocessados. Os supermercados, por exemplo, oferecem ambas as opções, saudáveis e não saudáveis, enquanto que as lojas de conveniência oferecem mais alimentos industrializados, bebidas açucaradas e pouca ou nenhuma variedade de frutas e verduras ${ }^{37-42,51}$. Para as mercearias, os dados encontrados são contraditórios, pois enquanto alguns autores mostram a disponibilidade de alimentos saudáveis, outros indicam pouca ofertas destes alimentos ${ }^{46,52-54}$.

$\mathrm{Na}$ atual pesquisa foram encontradas evidências de diferenças na localização dos comércios e na oferta de alimentos saudáveis pelas características dos buffers onde estavam instalados. Buffers de menor renda tendiam a ter maior número de supermercados e mercearias do que os de maior renda, enquanto o inverso foi encontrado para as lojas de conveniência, mais comuns nestes últimos. Quando os comércios foram comparados, os supermercados, as mercearias e as fruterias disponibilizavam mais alimentos saudáveis do que lojas de conveniência.

Supermercado e mercearia estavam inversamente correlacionados às lojas de conveniência e à renda média do buffer, ou seja, quanto maior o número de supermercados e mercearias, menor de número de lojas de conveniênica e menor a média de renda do buffer. Em relação à população, supermercado, mercearias e fruteiras estavam diretamente correlacionadas, ou seja, quanto mais populoso o buffer, maior o número de comércios. O contrário foi percebido para as lojas de conveniência. Outros estudos disponíveis na literatura mostram que vizinhanças com maior vulnerabilidade apresentam maior número de comércios de alimentos, porém, de menor qualidade $^{45,55-57}$. Já em 1999, estudo com dados do ambiente alimentar de Glasgow apontava que bairros com menor nível socioeconômico apresentavam o maior número de lojas, sendo as pequenas mercearias as mais frequentes, enquanto que os bairros com moradores com alto nível socioeconômico tinham um menor número de $\operatorname{lojas}^{58}$. Estudo desenvolvido com adultos americanos apontou que os participantes que viviam em áreas mais populosas relataram a existência de maior número de supermercados quando comparados aos que viviam em locais com menor densidade populacional ${ }^{42}$.

Uma possível explicação é que pessoas com menor poder aquisitivo buscam moradias de menor custo, localizadas em bairros altamente populosos, onde comércios de ali- 
mentos estão localizados, pois a densidade populacional é um fator determinante na distribuição dos comércios de alimentos ${ }^{57,59-61}$. $\mathrm{Na}$ atual pesquisa percebeu-se que a qualidade dos alimentos disponíveis nos comércios de alimentos variou conforme a renda e o número de moradores do buffer. Maiores escore do NEMS, apontando para a maior oferta de alimentos saudáveis, foram encontrados nos buffers de maior renda e menos populosos. Menezes e colaboradores $^{26}$, ao analisarem o consumo de frutas e verduras e sua relação com o ambiente na cidade de Belo Horizonte, Minas Gerais, encontraram uma variação geográfica do consumo nas diferentes áreas avaliadas. $\mathrm{O}$ consumo de frutas e verduras foi maior naquelas áreas com maior renda e concentração de comércios de alimentos, e apresentou um melhor índice de acesso a alimentos saudáveis quando comparado a regiões com menor número de comércios, sobretudo os de alimentos saudáveis ${ }^{26}$. Dados semelhantes foram encontrados por estudos internacionais, e que apontaram que a maior exposição a comércios de alimentos saudáveis foi significativamente associada a maior ingestão de frutas e verduras, ao contrário das lojas de conveniência, consideradas não saudáveis, que aparecem como um fator de risco para o consumo de frutas e verduras ${ }^{21,29,62-65}$.

Nossos resultados são consistentes com a literatura existente que aponta que indivíduos que vivem em comunidades com maior vulnerabilidade social apresentam maior dificuldade de acesso a alimentos saudáveis ${ }^{17-20,39,40,66-69}$. Estes indivíduos, na sua maioria, não têm condições financeiras para obter produtos alimentares em comércios fora da sua vizinhança, logo os pequenos comércios do bairro acabam por serem as únicas opções de compra, com preços mais elevados e qualidade dos alimentos limitada ${ }^{16,25,70-73}$.

A dificuldade dos pequenos supermercados de bairro em oferecer produtos frescos está relacionada ao custo de abastecimento, pois distância e acessibilidade acabam por enfluenciar o preço do produto. Estes comércios não possuem estrutura física de refrigeração para conseguir manter os produtos frescos, o que dificulta a oferta à população que vive no entorno.

Os resultados deste estudo, entretanto, devem ser discutidos considerando-se algumas limitações metodológicas. A primeira limitação está relacionada à média de renda e população do buffer. Embora realizada a análise da qualidade de informação, os dados dizem respeito a uma média de um dado secundário, que podem estar sujeitos a imprecisões. E, também, o tamanho do buffer de 400m do centroide das residências, ao entender que as mulheres possam extrapolar esta área ao adquirirem seus alimentos.

Os pontos fortes do nosso estudo incluem a utilização de dados primários, com a identificação de todos os comércios presentes na área geográfica demarcada, indicados por listagens oficiais, e não apenas aqueles formais. Outro ponto é a avaliação in loco dos comércios de alimentos, e que identifica a disponibilidade de alimentos comercializados, ainda, a diversidade de comércios avaliados e o uso de um instrumento validado no Brasil. Todos estes dados foram analisados a partir de um processo com múltiplos estágios e que visou a representatividade das mulheres de São Leopoldo.

\section{Conclusão}

Em conclusão, encontramos diferenças na disponibilidade de comércios de alimentos em buffers de distintos níveis de renda e número de moradores no município de São Leopoldo. A disponibilidade de alimentos saudáveis se mostrou mais elevada em áreas de maior renda e menor número de moradores. Esses achados sugerem que as diferenças espaciais no acesso aos alimentos podem contribuir para as desigualdades na saúde. 


\section{Colaboradores}

V Backes fez as análises de dados e escreveu o artigo. CB Cafruni participou de todas as etapas de coleta de dados. JSD Costa coordenou a coleta de dados. FS Bairros coordenou a coleta de dados. MTA Olinto coordenou a coleta de dados, participou das análises de dados e auxiliou na escrita do artigo.

\section{Referências}

1. Brasil. Ministério da Saúde (MS). Perspectivas e desafios no cuidado às pessoas com obesidade no SUS: resultado do Laboratório de Inovação no manejo da obesidade nas Redes de atenção à Saúde. Brasília: MS; 2014.

2. Organização Mundial da Saúde (OMS). Enfoques populacionais e individuais da prevenção e tratamento de diabetes e obesidade. Genebra: OMS; 2008.

3. Casey AA, Elliott M, Glanz K, Haire-Joshu D, Lovegreen SL, Saelens BE, Sallis JF, Brownson RC. Impact of the food environment and physical activity environment on behaviors and weight status in rural U.S. communities. Prev Med 2008; 47(6):600-604.

4. Creatore MI, Glazier RH, Moineddin R, Fazli GS, Johns A, Gozdyra P, Matheson FI, Kaufman-Shriqui V, Rosella LC, Doug G, Manuel DG, Booth GL. Association of Neighborhood Walkability With Change in Overweight, Obesity, and Diabetes. Jama 2016; 315(20):2211-2220.

5. Dalton AM, Jones A, Ogilvie D, Petticrew M, White $\mathrm{M}$, Cummins $\mathrm{S}$. Using spatial equity analysis in the process evaluation of environmental interventions to tackle obesity: the healthy towns programme in England. Int J Equity Health 2013 12(43);12:43.

6. Glanz K, Johnson L, Yaroch AL, Phillips M, Ayala GX, Davis EL. Measures of Retail Food Store Environments and Sales: Review and Implications for Healthy Eating Initiatives. J Nutri Educ Behavior 2016; 48(4):280-288.e1.

7. Krieger N. Historical roots of social epidemiology: socioeconomic gradients in health and contextual analysis. Int J Epidemiol 2001; 30(4):899-900.

8. Snow J. Sobre a maneira de transmissão do cólera. $2^{\mathrm{a}} \mathrm{ed}$. São Paulo: Hucitec; 1990.

9. Engels F. A situação da classe trabalhadora na Inglaterra: segundo as observações do autor e fontes autênticas Col. Marx \& Engels. [cerca de 384 p.] São Paulo: Boitempo; 2008.

10. Vasconcelos FR. O nutricionista no Brasil: uma análise histórica. Rev Nutr 2008; 15(2):127-138.

11. Kumanyika S. INFORMAS (International Network for Food and Obesity/non-communicable diseases Research, Monitoring and Action Support): summary and future directions. Obes Rev 2013; 14(Supl. 1):157-164.

12. Canesqui AMG, Garcia RWD. Uma introdução à reflexão sobre a abordagem sociocultural da alimentação. In: Canesqui AMG, Garcia RWD, organizadoras. Antropologia e nutrição: um diálogo possível. Rio de Janeiro, Ed. Fiocruz; 2005.

13. Quaioti TCBA, Almeida SS. Determinantes psicológicos do comportamento alimentar: uma ênfase em fatores ambientais que contribuem para a obesidade. Psicologia USP 2016;17(4):193-211.

14. Lopez RP. The built environment and public health. Hoboken: Jossey-Bass; 2012.

15. Gartin M. Food deserts and nutritional risk in Paraguay. Am J Hum Biol 2012; 24(3):296-301.

16. Walker RE, Keane CR, Burke JG. Disparities and access to healthy food in the United States: A review of food deserts literature. Health Place 2010; 16(5):876884 . 
17. Bodor JN, Rice JC, Farley TA, Swalm CM, Rose D. Disparities in food access: does aggregate availability of key foods from other stores offset the relative lack of supermarkets in African-American neighborhoods? Prev Med 2010; 51(1):63-67.

18. Giskes K, van Lenthe F, Avendano-Pabon M, Brug J. A systematic review of environmental factors and obesogenic dietary intakes among adults: are we getting closer to understanding obesogenic environments? Obes Rev 2011; 12(5):e95-e106.

19. Kerr J, Frank L, Sallis JF, Saelens B, Glanz K, Chapman J. Predictors of trips to food destinations. Int J Behav Nutr Phys Act 2012; 9:(58).

20. Minaker LM, Shuh A, Olstad DL, Engler-Stringer R, Black JL, Mah CL. Retail food environments research in Canada: A scoping review. Can J Public Health 2016; 107(Supl.1):5344.

21. Pitts SBJ, Acheson MLM, Ward RK, Wu Q, McGuirt JT, Bullock SL, Lancaster MF, Raines J, Ammerman AS. Disparities in healthy food zoning, farmers' market availability, and fruit and vegetable consumption among North Carolina residents. Archives of public health. Arch Belg Sante Publique 2015; 73(1):35.

22. Pessoa MC, Mendes LL, Gomes CS, Martins PA, Velasquez-Melendez G. Food environment and fruit and vegetable intake in a urban population: a multilevel analysis. BMC public health 2015;15:1012.

23. Widener MJ, Metcalf SS, Bar-Yam Y. Dynamic urban food environments a temporal analysis of access to healthy foods. Am J Prev Med 2011; 41(4):439-441.

24. Duran AC, Diez Roux AV, Latorre Mdo R, Jaime PC. Neighborhood socioeconomic characteristics and differences in the availability of healthy food stores and restaurants in Sao Paulo, Brazil. Health Place 2013; 23:39-47.

25. Jaime PC, Duran AC, Sarti FM, Lock K. Investigating environmental determinants of diet, physical activity, and overweight among adults in Sao Paulo, Brazil J Urban health 2011; 88(3):567-581.

26. Menezes MC, Costa BV, Oliveira CD, Lopes AC. Local food environment and fruit and vegetable consumption: An ecological study. Prev Med Reports 2017; 5:13-20.

27. Lytle LA, Sokol RL. Measures of the food environment: A systematic review of the field, 2007-2015. Health Place 2017; 44:18-34.

28. Glanz K, Sallis JF, Saelens BE, Frank LD. Healthy nutrition environments: concepts and measures. American journal of health promotion: Am J Health Promot $2005 ; 19(5): 330-3$, ii.

29. Clary C, Lewis DJ, Flint E, Smith NR, Kestens Y, Cummins S. The Local Food Environment and Fruit and Vegetable Intake: A Geographically Weighted Regression Approach in the ORiEL Study. Am J Epidemiol 2016; 184(11):837-846.

30. Mason KE, Bentley RJ, Kavanagh AM. Fruit and vegetable purchasing and the relative density of healthy and unhealthy food stores: evidence from an Australian multilevel study. J Epidemiol Community Health 2013; 67(3):231-236.

31. Instituto Brasileiro de Geografia e Estatística (IBGE). Censo Demográfico 2010. Rio de Janeiro: IBGE; 2010.

32. Brownson RC, Hoehner CM, Day K, Forsyth A, Sallis JF. Measuring the built environment for physical activity: state of the science. Am J Prev Med 2009; 36(Supl.4):S99-123.e12.
33. Glanz K, Sallis JF, Saelens BE, Frank LD. Nutrition Environment Measures Survey in stores (NEMS-S): development and evaluation. Am J Prev Med 2007; 32(4):282-289.

34. Martins PA, Cremm EC, Leite FH, Maron LR, Scagliusi FB, Oliveira MA. Validation of an adapted version of the nutrition environment measurement tool for stores (NEMS-S) in an urban area of Brazil. J Nutr Educ Behav 2013; 45(6):785-92.

35. Chow CK, Lock K, Madhavan M, Corsi DJ, Gilmore AB, Subramanian SV, Li W, Swaminathan S, LopezJaramillo P, Avezum A, Lear SA, Dagenais G, Teo K, McKee M, Yusuf S. Environmental profile of a community's health (EPOCH): an instrument to measure environmental determinants of cardiovascular health in five countries. PLoS One 2010; 5(12):e14294.

36. Instituto Brasileiro de Geografia e Estatística (IBGE). Pesquisa de orçamentos familiares, 2008-2009. Avaliação nutricional da disponibilidade domiciliar de alimentos no Brasil. Rio de Janeiro: IBGE; 2010.

37. Black C, Ntani G, Inskip H, Cooper C, Cummins S, Moon G, Baird J. Measuring the healthfulness of food retail stores: variations by store type and neighbourhood deprivation. Int J Behav Nutr Phys Act 2014;11:69.

38. Block D, Kouba J. A comparison of the availability and affordability of a market basket in two communities in the Chicago area. Public Health Nutr 2006; 9(7):837-845.

39. Franco M, Diez Roux AV, Glass TA, Caballero B, Brancati FL. Neighborhood characteristics and availability of healthy foods in Baltimore. Am J Prev Med 2008; 35(6):561-7.

40. Gittelsohn J, Sharma S. Physical, consumer, and social aspects of measuring the food environment among diverse low-income populations. Am J of Prev Med 2009; 36(Supl.4):S161-165.

41. Hilmers A, Hilmers DC, Dave J. Neighborhood disparities in access to healthy foods and their effects on environmental justice. Am J Public Health 2012; 102(9):1644-1654.

42. Moore LV, Diez Roux AV, Brines S. Comparing Perception-Based and Geographic Information System (GIS)-based characterizations of the local food environment. J Urban Health 2008; 85(2):206-216.

43. Herforth AA, S. The food environment, its effects on dietary consumption, and potential for measurement within agriculture-nutrition interventions. Food Security 2015;7:505-520.

44. Diez J, Bilal U, Cebrecos A, Buczynski A, Lawrence RS, Glass T, Escobar F, Gittelsohn J, Franco M. Understanding differences in the local food environment across countries: A case study in Madrid (Spain) and Baltimore (USA). Prev Med 2016; 89:237-44

45. Cannuscio CC, Tappe K, Hillier A, Buttenheim A, Karpyn A, Glanz K. Urban food environments and residents' shopping behaviors. Am J of Prev Med 2013;45(5):606-614.

46. Cavanaugh E, Mallya G, Brensinger C, Tierney A, Glanz K. Nutrition environments in corner stores in Philadelphia. Prev Med 2013;56(2):149-151.

47. Monteiro CA, Levy RB, Claro RM, de Castro IR, Cannon G. Increasing consumption of ultra-processed foods and likely impact on human health: evidence from Brazil. Public Health Nutr 2011; 14(1):5-13. 
48. Moubarac JC, Parra DC, Cannon G, Monteiro CA. Food Classification Systems Based on Food Processing: Significance and Implications for Policies and Actions: A Systematic Literature Review and Assessment. Curr Obes Rep 2014; 3(2):256-272.

49. Monteiro CA, Levy RB, Claro RM, Castro IR, Cannon G. A new classification of foods based on the extent and purpose of their processing. Cad Saude Publica 2010; 26(11):2039-2049.

50. Brasil. Ministério da Saúde (MS). Guia alimentar para a população brasileira. Brasília: MS; 2014.

51. Sharkey JR, Dean WR, Nalty CC, Xu J. Convenience stores are the key food environment influence on nutrients available from household food supplies in Texas Border Colonias. BMC Public Health 2013;13:45.

52. D'Angelo H, Suratkar S, Song HJ, Stauffer E, Gittelsohn J. Access to food source and food source use are associated with healthy and unhealthy food-purchasing behaviours among low-income African-American adults in Baltimore City. Public Health Nutr 2011; 14(9):1632-1639.

53. Pinard CA, Byker Shanks C, Harden SM, Yaroch AL. An integrative literature review of small food store research across urban and rural communities in the U.S. Prev Med Rep 2016; 3:324-332.

54. Stern D, Poti JM, Ng SW, Robinson WR, Gordon-Larsen P, Popkin BM. Where people shop is not associated with the nutrient quality of packaged foods for any racial-ethnic group in the United States. Am J Clin Nutr 2016; 103(4):1125-1134.

55. Lamichhane AP, Warren JL, Peterson M, Rummo P, Gordon-Larsen P. Spatial-temporal modeling of neighborhood sociodemographic characteristics and food stores. Am J Epidemiol 2015; 181(2):137-150.

56. Luan H, Minaker LM, Law J. Do marginalized neighbourhoods have less healthy retail food environments? An analysis using Bayesian spatial latent factor and hurdle models. Int J Health Geogr 2016; 15(1):29.

57. Polsky JY, Moineddin R, Glazier RH, Dunn JR, Booth GL. Foodscapes of southern Ontario: neighbourhood deprivation and access to healthy and unhealthy food retail. Can J Public Health 2014; 105(5):e369-75.

58. Cummins S, Macintyre, S. The location of food stores in urban areas: a case study in Glasgow. Br Food J 1999; 101(7):545-553.

59. Black JL, Carpiano RM, Fleming S, Lauster N. Exploring the distribution of food stores in British Columbia: associations with neighbourhood socio-demographic factors and urban form. Health Place 2011; 17(4):961-970.

60. Borrell C, Mari-Dell'olmo M, Serral G, Martinez-Beneito $\mathrm{M}$, Gotsens M. Inequalities in mortality in small areas of eleven Spanish cities (the multicenter MEDEA project). Health Place 2010; 16(4):703-711.

61. Wang H, Tao L, Qiu F, Lu W. The role of socio-economic status and spatial effects on fresh food access: two case studies in Canada. Appl Geogr 2016; 67:27-38.

62. Gustafson A, Christian JW, Lewis S, Moore K, Jilcott S. Food venue choice, consumer food environment, but not food venue availability within daily travel patterns are associated with dietary intake among adults, Lexington Kentucky 2011. Nutr J 2013; 12:17.
63. Lind PL, Jensen PV, Glumer C, Toft U. The association between accessibility of local convenience stores and unhealthy diet. Eur J Public Health 2016; 26(4):634-9.

64. Morland K, Wing S, Diez Roux A. The contextual effect of the local food environment on residents' diets: the atherosclerosis risk in communities study. Am J Public Health 2002; 92(11):1761-1767.

65. Reitzel LR, Okamoto H, Hernandez DC, Regan SD, McNeill LH, Obasi EM. The Built Food Environment and Dietary Intake among African-American Adults. Am J Health Behavior 2016; 40(1):3-11.

66. Baker EA, Schootman M, Barnidge E, Kelly C. The role of race and poverty in access to foods that enable individuals to adhere to dietary guidelines. Prev Chronic Dis 2006; 3(3):A76.

67. Beaulac J, Kristjansson E, Cummins S. A systematic review of food deserts, 1966-2007. Prev Chronic Dis 2009; 6(3):A105.

68. Larson NI, Story MT, Nelson MC. Neighborhood environments: disparities in access to healthy foods in the U.S. Am J Prev Med 2009; 36(1):74-81.

69. Morland KB, Evenson KR. Obesity prevalence and the local food environment. Health Place 2009; 15(2):491495.

70. Bovell-Benjamin AC, Hathorn CS, Ibrahim S, Gichuhi PN, Bromfield EM. Healthy food choices and physical activity opportunities in two contrasting Alabama cities. Health Place 2009; 15(2):429-438.

71. Cummins S, Macintyre S. Food environments and obesity-neighbourhood or nation? Int J Epidemiol 2006; 35(1):100-104.

72. Glanz K, Basil M, Maibach E, Goldberg J, Snyder D. Why Americans eat what they do: taste, nutrition, cost, convenience, and weight control concerns as influences on food consumption. J Am Diet Assoc 1998; 98(10):1118-1126.

73. Zachary DA, Palmer AM, Beckham SW, Surkan PJ. A framework for understanding grocery purchasing in a low-income urban environment. Qual Health Res 2013; 23(5):665-78.

Artigo apresentado em 01/11/2018

Aprovado em 01/08/2019

Versão final apresentada em 03/08/2019

Editores-chefes: Romeu Gomes, Antônio Augusto Moura da Silva 